\title{
ISOLATION AND MOLECULAR IDENTIFICATION OF BHV-1 FROM CATTLE SUFFERING FROM RESPIRATORY SIGNS
}

\author{
*Nahed, A. Mahmoud and ${ }^{* *}$ G.H. Salem \\ *Virology Department, Animal Health Institute \\ ** Biotechnology Department, Animal Health Institute
}

\begin{abstract}
A total of 93 ocular, 50 nasal swabs and 10 lung tissue were collected from 2-3 years old cattles affected with respiratory manifestation, and 145 serum samples from in contact apparently healthy cattles distributed in 4 different Governorates of Egypt (Ismalia, Qalioubia, Kafr El-Sheikh, and EL-Fayoum). Swabs and lung tissue samples were subjected to Bovine Herpes Virus (BHV-1) isolation on tissue culture Medin -Darby Bovine Kidney (MDBK) cell line and isolates were identified by direct fluorescent antibody technique (FAT) and polymerase chain reaction (PCR) by using primers complementary to the sequence of BHV-1 glycoprotein $\mathrm{gB}$ gene, as a rapid and more sensitive technique. From the results of virus isolation and identification were confirmed the more sensitivity of virus isolation than FAT and the most sensitivity and rapidity of PCR technique with confirmation and agreement of its results with the conventional methods. BHV-1 specific antibodies was detected in serum samples collected from the same 4 different Governorate, because of virus latency is a normal sequel to BHV-1 infection, by using the most suitable, sensitive, rapid, and specific techniques are ELISA and serum neutralization test (SNT), it is clear that the highest percentage of positive BHV-1 serum reactors was, in Kafr El-Sheikh followed by Ismalia, and Qalioubia and the lowest percentage was in EL-Fayoum. By the detection and identification of BHV-1 in collected samples and presence of positive reactors in serum samples this was a good indication for the circulation of BHV-1 in cattles of Egypt.
\end{abstract}




\section{INTRODUCTION}

Bovine herpes virus 1 (BHV-1), is a member of the family Herpesviridae and Alphaherpesviridae subfamily (Meurens et al., 2004), classified in the list B of the Office International des Epizooties (OIE) (Winkler et al., 2000).

BHV-1 is an important viral pathogen worldwide in cattle that causes two major disease syndromes: infectious bovine rhinotracheitis (IBR), infectious pustularvulvovaginitis and balanoposthitis (IPV/IBP) (Taylor et al., 1998; Meurenset al., 2004), cattle of all ages and breeds are susceptible to infection, other Artiodactyla (e.g. goats, sheep, water buffaloes, camelids) may be infected with BHV-1.The virus can infect many wild life species as judged by the detection of BHV-1 specific antibodies (Straub 1978). The clinical signs displayed are dependent on the virulence of the strain; BHV-1 can cause both clinical and subclinical infections depending on the virulence of the strain (Winkler et al., 2000).IBR is the respiratory form of the disease, characterized by clinical signs of the upper respiratory tract infection (red nose disease), and abortions, the acute form of the disease in dairy cattle is usually accompanied by a severe and prolonged drop in milk production, secondary bacterial infections resulting in bronchopneumonia and death are common. The virus can also infect the genital tract and cause IPV/IBP disease, that is usually not observed in respiratory outbreaks (and vice versa) (Kahrs and Smith 1965) and morbidity rate can reach $100 \%$, while mortality is low with maximum around $10 \%$ (Straub 1990). Although these symptoms are mainly non-life threatening, it is an economically important disease as infection may cause a drop in production, mortality and affect trade restrictions (Muylken et al., 2007; and Nandi et al., 2009). 
It is spread horizontally through sexual contact, artificial insemination, and aerosol transmission and it may also be transmitted vertically across the placenta (Van Engelenburg et al., 1995)

Like other herpes viruses, BHV-1 causes a lifelong latent infection and sporadic shedding of the virus. The sciatic nerve and trigeminal nerve are the sites of latency. A reactivated latent carrier is normally the source of infection in a herd Infected animals will be continuous shedders throughout their lifetime when the virus reactivates therefore, successfully propagating the disease (DerKoeijer et al., 2008).

Prevention and control of BHV-1 infections are based on thorough farm management including hygienic measures, vaccination schedules with live attenuated or inactivated vaccines (Taylor et al., 1998). The viral genome consists of double-stranded DNA that encodes for about 70 proteins, of which 33 structural and more than 15 nonstructural proteins have been identified. The viral glycoproteins, which are located in the envelope on the surface of the virion, play an important role in pathogenesis and immunity. The glycoproteins C, D, E, G and I, in UL49h and thymidine kinase proteins are involved in viral virulence and are useful targets for diagnosis, and prevention or antiviral treatment (Liang et al., 1997 andKaashoek et al., 1998).

Although clinical findings may be highly suggestive of BHV-1, no real pathognomonic signs provide a clinical diagnosis of IBR. Therefore, laboratory confirmation is necessary to identify BHV-1 infection and to make a definite diagnosis of BHV-1 infection. Virus isolation in cell culture is the most frequently used method to detect BHV-1 in samples (Drew et al., 1987). Currently, new techniques like PCR to detect the 
presence of the virus in nasal secretions and tissues are available. The major advantages of PCR assay are its sensitivity, specificity, and rapidity BHV-1 infections in animals are usually diagnosed using serological tests such as ELISA or serum neutralization assays, these tests are generally efficient and sensitive (Cho and Bohac,1985\&Perrin et al.,1993).

In Egypt the first isolation of IBR was reported by (Fathehia, 1974 and Hafez et al., 1974). The genital form was isolated in El-Fayoum governorate by (Madbouly and Hussein, 1997). The virus was also isolated from nasal swab of sheep and goats in Giza (Salem et al., 2000 and Mahmoud and Ahmed, 2009).

\section{The Aim of this Work:}

The trial of isolation and characterization of the virus that causes respiratory disorders in different herds of cattles and may causing mortality, by using accurate, rapid, and sensitive techniques like virus isolation in cell culture, identification of the isolates by fluorescent antibody technique (FAT) and polymerase chain reaction(PCR). The detection of antibodies in serum samples was detected by using ELISA kits, and serum neutralization tests (SNT).

\section{MATERIAL AND METHODS}

\section{1- Sampels:}

A- a total of 93 ocular and 50 nasal swabs were collected from affected cattle with respiratory manifestations distributed in 4 different Governorates (Ismailia, Qalioubia, Kefir El-Sheikh, and ELFayoum) in Egypt. The samples were collected in the early phase of

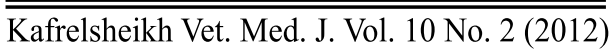


infection, the cattle still have serous rather than mucopurulent nasal discharge. The swab were dipped in Eagle's MEM containing antibiotics, thoroughly shacked and centrifuged at $3000 \mathrm{rpm}$ for 30 $\min$ at $4^{\circ} \mathrm{C}$ and the supernatant was labeled and stored at $-70^{\circ} \mathrm{C}$ for virological examination.

B- Tissue samples: a total of 10 lung tissue samples showing pathological changes were collected. The tissue samples were homogenized with the addition of MEM to obtain $10 \%$ suspension and centrifuged at $3000 \mathrm{rpm}$ for $30 \mathrm{~min}$ at $4^{\circ} \mathrm{C}$ and the supernatant was labeled and stored at $-70^{\circ} \mathrm{C}$ for virological examination.

C- Serum samples: a total of 145 serum samples were collected from apparently healthy cattles in contact with diseased animals distributed in the 4 different Governorates for detection of antibodies against BHV-1. Table (1) indicated the type, number and location of collected samples.

Table (1): Number of ocular, nasal swabs, lung tissues and serum samples collected from infected cattles in different governorates of Egypt.

\begin{tabular}{|c|c|c|c|c|}
\hline Governorates & No. of nasal swabs & No. of ocular swabs & No. of lung tissues & No. of serum samples \\
\hline Ismailia & 12 & 23 & 3 & 40 \\
\hline Qalioubia & 10 & 17 & 2 & 15 \\
\hline Kafir El-Sheikh & 15 & 28 & 2 & 35 \\
\hline EL-Fayoum & 13 & 25 & 3 & 55 \\
\hline Total & 50 & 93 & 10 & 145 \\
\hline
\end{tabular}




\section{2- Cell Culture:}

Medin-Darby bovine kidney (MDBK) cell line, it was kindly supplied and propagated at Animal Health and Research Institute (AHRI), Virology Department, DOKKI, Egypt. Eagle's Minimum Essential Medium (MEM) supplemented with $10 \%$ fetal calf serum (Sigma) was used for cell growth.

\section{3- Specific Antisera and Reference Materials:}

a- a standard strain of BVH-1(Colorado strain), it was kindly supplied and propagated at Virology Department, (AHRI), DOKKI, Egypt. The virus strain has been stored at $-80^{\circ} \mathrm{C}$.

b- Specific anti- IBR hyperimmune serum conjugated with fluorescine isothiocynate Supplied by Central Vet.Lab. New. Haw. Weybridge, UK.

\section{4-Virus Isolation:}

All nasal, ocular swabs and lung tissue samples were prepared and propagated on MDBK cells for virus isolation according to (Kahrs, 1977), MDBK cell line was grown in flat bottom 24well plates (Coastar), 1 day old monolayer of MDBK cells was inoculated with 100- $200 \mu \mathrm{l}$ of the sampel/well. The plates were incubated for $1 \mathrm{~h}$ at $37^{\circ} \mathrm{C}$ and then the inoculums was replaced with maintenance medium (Eagle's MEM with addition of $2 \%$ foetal calf serum) and incubated at $37^{\circ} \mathrm{C}$ in $5 \% \mathrm{CO} 2$ atmosphere, control non infected cells were involved, each sample was inoculated in cell culture for a three blind passages, infected MDBK cells were examined microscopically daily for the presence of cytopathic effect (CPE), in each passage the cells were observed for changes for seven days. Sample that did not show a cytopathic effect (CPE) by the

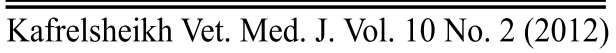


third passage were discarded and treated as negative. Samples that produced CPE by the third passage were further passaged for virus propagation (Anonymous, 2008). The CPE comprised rounding of cells 48-72 hr post infection (PI) with the characteristic "bunch of grapes" like aggregation developed by $72 \mathrm{hr}$, finally leading to complete destruction of the cell sheet by 96-120 hrs. In each time the cell culture is freezethawed for 3times and clarified by centrifugation, and the supernatant is used for inoculation of fresh monolayers (Edwards et al., 1983 and Brunner et al., 1988).

\section{5- Direct Fluorescent Antibody Technique:}

It was done according to Payment and Trudel (1993), the test was carried out on fixed inoculated cell.

\section{6- Polymerase Chain Reaction (PCR):}

DNA from nasal and ocular swabs and lung specimens was extracted by using DNA extraction Qia Amp DNA kitt (Qiagen).Samples were amplified using PCR Ready touse PCR master Mix (Thermo, UK). The primers were selected on the basis of the published sequence of $\mathrm{gB}$ glycoprotein gene region of BHV-1 (Whitbeck et al., 1988), which was predicted to produce a PCR product of 468 base pairs (bp). CACGGACCTGGTGGACAAGAAG-3' position (624 - 645) and Ext R 5'-CTACCGTCACGTGAGTGGTACG-3.position

(10701091),(Synthesized by MWG Biotech AG Germany) were used for PCR amplification. The PCR was performed in 35 cycles; each temperature cycle consisted of $60 \mathrm{~s}$ at $95^{\circ} \mathrm{C}, 60 \mathrm{~s}$ at $57^{\circ} \mathrm{C}$ and $60 \mathrm{~s}$ at $72^{\circ} \mathrm{C}$. A final extension time of six minutes at $72^{\circ} \mathrm{C}$ was included at the end of last cycle. The PCR products were analyzed by agarose gel electrophoresis (2\% agarose) using $5 \mu \mathrm{L}$ of the each PCR product mixed with $10 \mu \mathrm{L}$ of loading dye. 


\section{7- Detection of BHV-1 Antibodies in Serum Samples:}

a- SYNBIOTICS (SERELISA BHV-1 Total Ab Mono Indirect) ELISA kits:

Indirect immunoenzymatic technique for the detection of antibodies to the virus of BHV-1in bovine serum plasma and milk samples was used in this study for the detection of BHV-1 specific antibodies in the collected serum samples.

b- The neutralization test was applied according to standard technique of

Bitsch (1978) with some modifications, using constant virus and diluted serum (Beta procedure). Standard BHV-1 (Colorado strain) was used after titration on MDBK cells.

\section{RESULTS}

Table (2): Incidence of BHV-1 in (nasal and ocular) swabs and lung tissues of affected cattles in 4 different Governorate in Egypt by different techniques.

\begin{tabular}{|c|c|c|c|c|c|c|c|c|c|}
\hline \multirow{3}{*}{ Governorate } & \multicolumn{9}{|c|}{ Type of samples } \\
\hline & \multicolumn{3}{|c|}{ Nasal swabs } & \multicolumn{3}{|c|}{ Ocular swabs } & \multicolumn{3}{|c|}{ Lung } \\
\hline & $\begin{array}{c}\text { Total } \\
\text { number }\end{array}$ & FAT & PCR & $\begin{array}{c}\text { Total } \\
\text { number }\end{array}$ & FAT & PCR & $\begin{array}{c}\text { Total } \\
\text { number }\end{array}$ & FAT & PCR \\
\hline Ismailia & 12 & 1 & 5 & 23 & 4 & 11 & 3 & 1 & 2 \\
\hline Qalioubia & 10 & 2 & 4 & 17 & 4 & 7 & 2 & 1 & 1 \\
\hline Kefir El-Sheikh & 15 & 3 & 9 & 28 & 10 & 21 & 2 & 1 & 2 \\
\hline EL-Fayoum & 13 & 2 & 5 & 25 & 5 & 12 & 3 & 1 & 2 \\
\hline Total & 50 & $\begin{array}{c}8 \\
(15.7 \%)\end{array}$ & $\begin{array}{c}23 \\
(45.1 \%)\end{array}$ & 93 & $\begin{array}{c}23 \\
(24.7 \%)\end{array}$ & $\begin{array}{c}51 \\
(54.8 \%)\end{array}$ & 10 & $\begin{array}{c}4 \\
(40 \%)\end{array}$ & $\begin{array}{c}7 \\
(70 \%)\end{array}$ \\
\hline
\end{tabular}

Kafrelsheikh Vet. Med. J. Vol. 10 No. 2 (2012) 

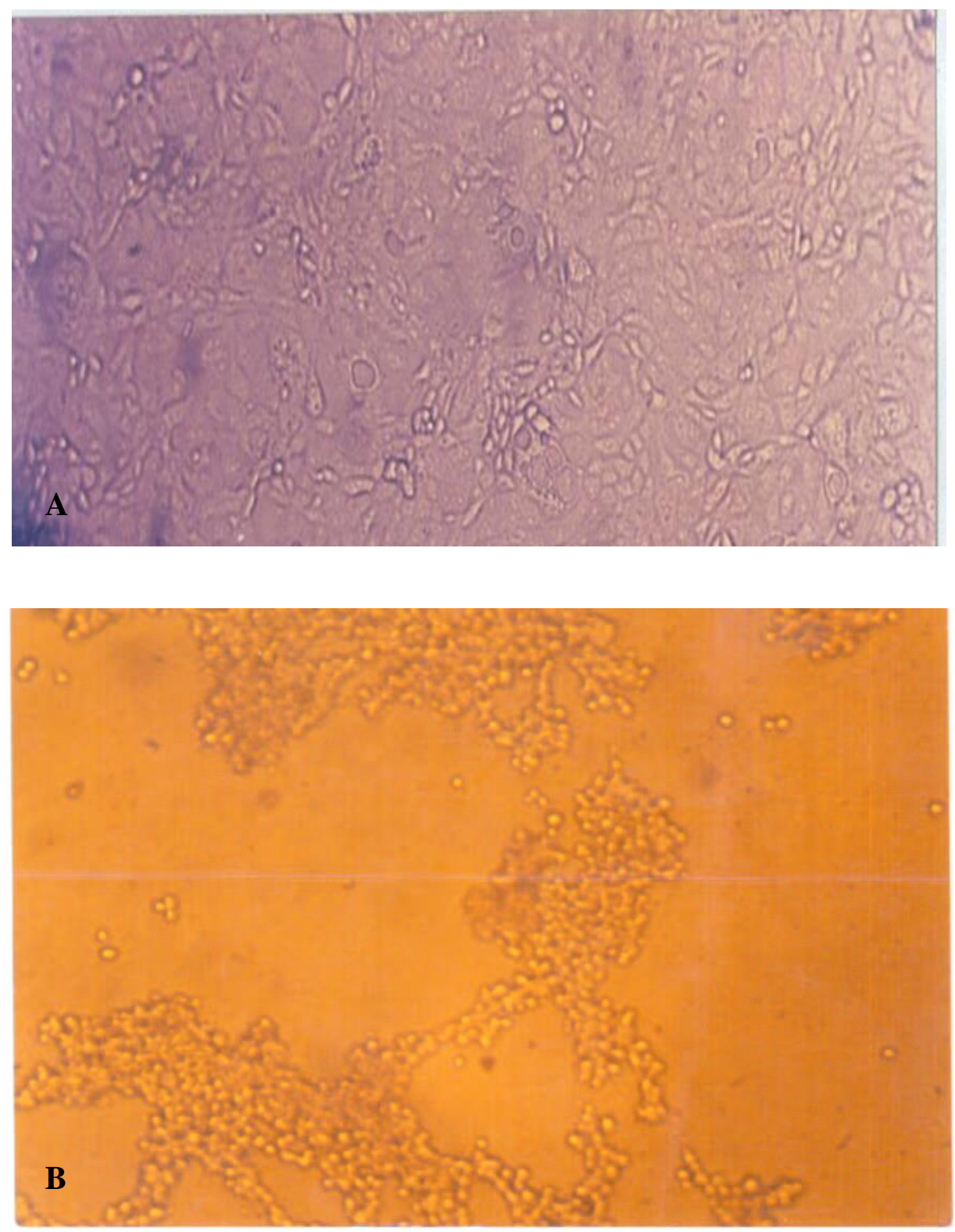

Photo (1): A: control non inoculated MDBK cells. (400X)

B: MDBK cells show CPE characterized by cell rounding, aggregation and detachment of cells. 


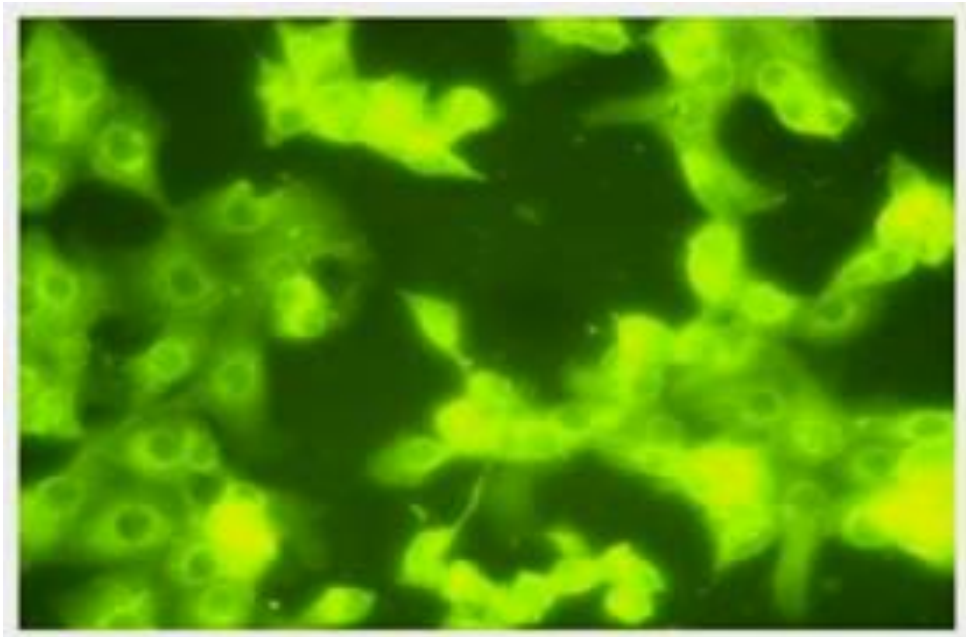

Photo (2): Infected MDBK cells showed perinuclear yellowish green fluorescent granule (400X).

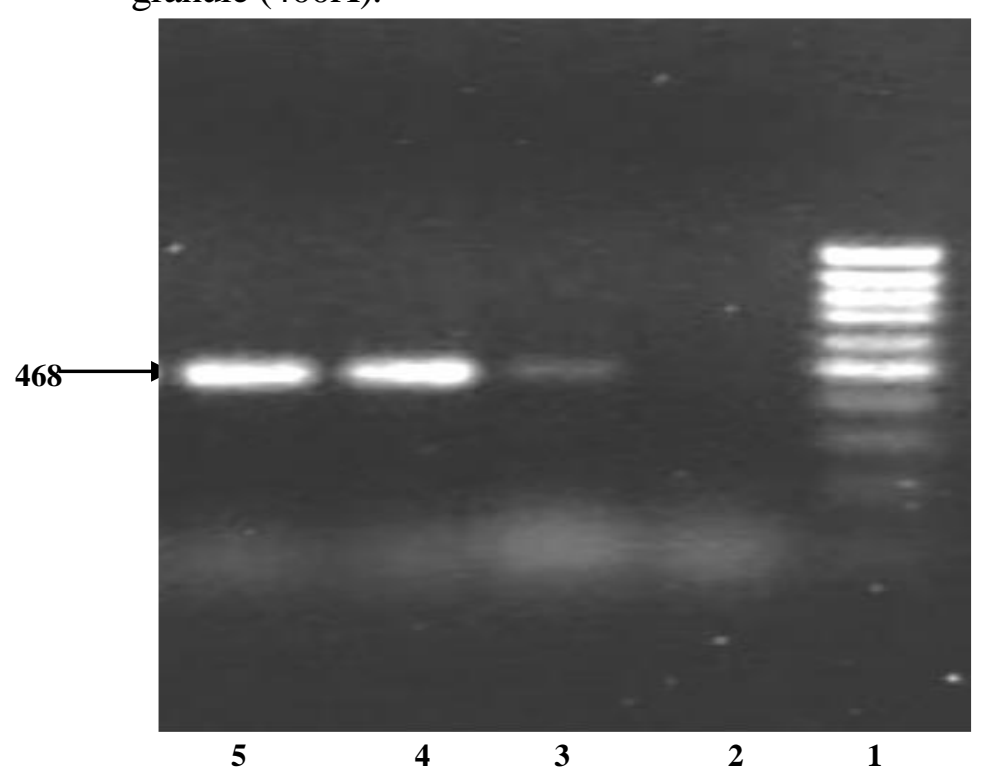

Photo (3): Characteristic PCR positive bands of 468bp size fragment of BHV-1.

Lane1: 100 bp molecular marker.

Lane 2: negative control.

Lane 3-5: suspected samples of BHV-1. 
Isolation And Molecular Identification Of ...

Table (3): Detection of BHV-1 specific antibodies in serum samples in 4 different Governorate in Egypt by using ELISA and serum neutralization test.

\begin{tabular}{|c|c|c|c|c|c|}
\hline \multirow{2}{*}{ Governorate } & \multirow{2}{*}{$\begin{array}{c}\text { Total No. of } \\
\text { samples }\end{array}$} & \multicolumn{2}{|c|}{ ELISA } & \multicolumn{2}{|c|}{ SNT } \\
\hline & & No. Of +ve & $\%$ of +ve & No. of +ve & $\%$ of + ve \\
\hline Ismalia & 40 & 17 & $42.5 \%$ & 11 & $27.5 \%$ \\
\hline Qalioubia & 15 & 5 & $33.3 \%$ & 4 & $26.7 \%$ \\
\hline Kafr El-Sheikh & 35 & 17 & $48.6 \%$ & 12 & $34.3 \%$ \\
\hline EL-Fayoum & 55 & 17 & $30.9 \%$ & 11 & $20 \%$ \\
\hline
\end{tabular}

\section{DISCUSSION}

Bovine herpesvirus-1(BHV-1) is considered one of the most important viral diseases of cattle. Herpes virus infections have been reported from all continents and most countries in the world causing serious economic losses in animal industry (Straub and Mackle, 1965) due to respiratory and reproductive disorders and mortalities caused by secondary bacterial infection resulting in pneumonia and death (Winkler et al., 1999). In the present study, due to the appearance of respiratory disorders (ocular, nasal discharge), conjunctivitis accompanied by pyrexia, anorexia, fever, and deaths due to secondary bacterial infection may suggested that the suspected disease was the respiratory form of BHV-1 infection. Such suspicion was primarily supported by the appearance of a characteristic cytopathic effect by propagation of the collected samples on MDBK cells, the cells that are the most widely used for BHV-1 propagation (Stevens and Groman, 1963), after three blind passages CPE started with rounding, granulation, shrinkage and 
aggregation of cells that lead to the grape like cluster appearance "bunch of grapes" within 2-4 days post inoculation that become more pronounced and reduced in time of appearance by advanced propagation on the cells (photo 1). The finding of CPE of BHV-1 with the appearance of the virus infected cells was in correlation with previous BHV-1 isolation studies (Edwards et al., 1986 and Murphy et al., 1999) and that the diagnosis of BHV-1 usually occurs by isolation of the virus. The overall percentage for the incidence of $\mathrm{BHV}-1$ in the examined samples revealed that the lung tissue is more suitable for isolation of BHV-1 in relation to nasal and ocular swabs in the different governorates (Table 2),this agrees with that examined by Ibrahim et al.,(2001).

FAT was used for the identification of the cytopathic viral agents, which is the most commonly test used for identification of BHV-1 by using standard conjugated anti sera with fluorescine isothiothianate. The inoculated positive samples on MDBK showed perinuclear yellowish green fluorescent granules (photo 2) (table 2). The results obtained by FAT were agreed with that reported by (Mohanty and Dutta, 1981), the isolation of BHV-1 from examined samples of infected animal which then confirmed by fluorescent test was agreed with (Hostnik and Zelzenik, 1992 and Foldi et al., 1992).

Polymerase Chain Reaction (PCR), the target region for amplification must be present in all BHV-1 strains, and its nucleotide sequence must be conserved. The $\mathrm{TK}, \mathrm{gB}, \mathrm{gC}, \mathrm{gD}$ and $\mathrm{gE}$ genes have been used as targets for PCR amplification (Fuchs et al., 1999; Schynts et al., 1999). 
Identification of BHV-1 by PCR, the primer sequence is based on the DNA sequence of BHV-1 gB gene according to (Whitbeck et al.; 1988) to produce a PCR product of $468 \mathrm{bp}$ fragment (photo 3 ). (Santurde et al.; 1996) said that a rapid and highly sensitive test for detection of BHV-1 in clinical samples was based on PCR amplification of highly conserved DNA fragment within the glycoprotein $\mathrm{gB}$, that agree with our results. Table (2) demonstrated the results of PCR technique. A number of studies have shown that PCR assays are more sensitive than virus isolation. The PCR assay detected BHV-1 shedding in samples earlier, more often, and for a longer duration, than did the virus isolation method (Smits et al., 2000; Wang et al., 2008).

On the other hand PCR as a result, was available in one day, where the virus isolation requires from 10-17 days (Amin and Ibrahim, 1998). From all the previous results , FAT, the antigen-detection technique has an advantage, it can lead to a same-day diagnosis, in other with the sensitivity of this procedure is lower than that of virus isolation or PCR; all of these were agree with the results of Edwards et al., (1983) and the demonstration of high percentage of positive reactors, beside the clinical symptoms of respiratory manifestation was indicative for active virus exposure (Adair, 1986 and Nawal, 1997) that agrees with our study.

Because of virus latency is a normal sequel in BHV-1 infection, the identification of serologically positive animals provides a useful and reliable indicator of infectious status, so that the serum samples in our study were examined for the detection of specific antibodies against BHV-1, using SNT and ELISA techniques. Virus neutralization (VN) tests (Bitsch, 1978) and various ELISA Kramps et al., (1993) are usually 
used for detecting antibodies against BoHV-1 in serum. Any animal with antibodies to the virus is considered to be a carrier and potential intermittent excretory of the virus. The results in table (3) proved that ELISA is more sensitive than SNT and this agree with that reported by (Cho et al.,2002 and Mahmoud and Ahmed, 2009), also ELISA used as rapid screen test for the disease (Durham and Sillers, 1986), and it appear superior test for BHV-1 diagnosis (Cho and Bohac, 1985).

In conclusion, BHV-1 was isolated by propagation on MDBK cell line and undergo to identification by different techniques (FAT and PCR).This finding was also supported by screening of antibody to BHV1 in serum samples at different localities, all of them will determine the widely prevalence of circulating BHV-1among cattle in Egypt, also confirmed the sensitivity of ELISA test in comparing to SNT and the usefulness of PCR technique in BHV-1 laboratory diagnosis ,the test was found to be more sensitive and rapid in comparison to virus isolation and FAT test.

\section{REFERENCES}

- Adair, B.M. (1986): "Parainfluenza type -3 and respiratory syncytial virus infection in calves." Res. Vet. Sci., 41: 414-418.

- Amin, A.S. and Ibrahim, A.K. (1998): "Detection of bovine herpes virus type 1 in semen using arapid and sensitive polymerase chain reaction." Vet. Med. J. G., 46: 463- 469.

- Bitsch, V. (1978):"The P 37/24 modification of the Infectious bovine rhinotracheitis virus serum neutralization test."Acta. Vet. Scand., 19:497-505. 
- Cho, H.J., Entz, S.C.; Creen, T. and Jordanh, T. (2002): "A bloking ELISA with improved sensitivity for the detection of passively acquired maternal antibodies to BHV-1." Cand. Vet. J., 43-45.

- Cho, H.J.; and Bohc, J.G. (1985):"Sensitivity and specificity of an enzyme-linked immunosorbentassay for the detection of infectious bovine rhinotracheitis viral antibodyin cattle."Can.J.Comp.Med., 4:189-194.

- Der Koeijer, A.; Diekmann, O.; and de Jong, M. (2008): "Calculating the time to extinction of a reactivating virus, in particular bovine herpes virus." Mathematical Biosciences 2008; 212:111-131.

- Durham and Sillers (1986): "Evaluation of ELISA for serodiagnosis of IBR with result of preliminary survey." New Zealand Vet. J., 34 (3): 27-30.

- Edwards, S.; Chasey, D.; and White, H. (1983): " Experimental infectious bovine rhinotracheitis: comparison of fourantigen detection methods." Res. Vet. Sci., 34: 42-45.

- Edwards, S.; Woods, S.B.; Westcotl, D.G.; Emmerson, M.; Jones,P.C. and Phillips, A.J. (1986): "An evaluation of live serological tests for the detection of antibody to BHV-1 in vaccinated and experimentaly infected cattle." Res. Vet. Sci., 41:378-382.

- Fathehia, M.M. (1974): "Characterization and identification of Infectious Bovine Rhinotracheitis virus of calves in Egypyt." Master Thesis in Microbiology, Virology, Cairo Univ. 
- Foldi, J.; Tanyi, J.; Kaszanyitzky, E. and Rovasz,F. (1992):" Isolation of IBR virus from calves with keratoconjunctivitis. "Magyarallatorvosok- lopja. 47 (5): 202-206.

- Fuchs, M.; Hubert, P.; Detterer J. and Rziha H.J. (1999):"Detection of bovine herpesvirus type 1 in blood from naturally infected cattle by using a sensitive PCR that discriminates between wild-type virus and virus lacking glycoprotein." E. J. Clin. Microbiol. 37, 2498-2507.

- Hafez, S.M.; Baz, T.G.; Zahran,M. and Ahmed, Y.A. (1974): "Isolation and identification of infectious pustularvulvovaginitis from local cattle and buffaloes in Egypt."J.Egypt. Vet. Med. Ass., 38 (40): 45-53.

- Hostnik, P. and Zelzenik, Z. (1992): "Outbreaks of IBR in 2 herds of feed- dot cattle." Zboznik- veterinarske- fakulterte- univerzaLjubljana, 29 (1): 53-57.

- Ibrahim, A.K.; Amin, A.S. and Awad, W.S. (2001): "Evaluation of polymerase chain reaction (PCR) and DNA hybridization assay as diagnostic tools for diagnosis of bovine herpes virus type-1 (BHV-1) infection in dairy cows." J.Egy.Vet. Med. Ass. 61 (1): 115-124.

- Kaashoek, M.J.; Rijsewijk, F.A.; Ruuls, R.C.; Keil, G.M.; Thiry, E.; Pastoret, P.P.; and Van Oirschot, J.T. (1998):"Virulence, immunogenicity and reactivationof bovine herpesvirus 1 mutants with a deletion in the $\mathrm{gC}, \mathrm{gG}, \mathrm{gI}, \mathrm{gE}$ orin both the $\mathrm{gI}$ and $\mathrm{gE}$ gene." Vaccine, 16: 802-809. 
- Kahrs, R. F . (1977): "Infectious bovine rhinotracheitis :A review and update."J.Am. Vet.Med.Ass.171,1050-1064.

- Kahrs, R.F. and Smith, R.S. (1965): "Infectious bovine rhinotracheitis, infectious pustularvulvovaginitis and abortion in a New York dairy herd." Journal of the American Veterinary Medical Association, 146: 217-220.

- Kramps, J.A.; Quak, S.; WeerDmesster, K. and Oirschot, J.T. (1993): "Comparative study on sixteen enzyme linked immunosorbent assays for detection of antibodies to BHV-1 in cattle." Vet. Microb. 35: 11-21.

- Liang, X.; Chow, B.; and Babiuk, L.A. (1997): "Study of immunogenicity andvirulence of bovine herpesvirus 1 mutants deficient in the UL49homolog, UL49.5 homolog and dUTPase genes in cattle." Vaccine 15:1057-1064.

- Madbouly, H.M. and Hussien, M.M.(1997):" Isolation of BHV-1, from Dairy herd Genital form of infection". Alex J Vet.Scien.,13 (4):439-446.

- Mahmoud, M.A. and Ahmed, S.A. (2009): "Prevalence of Bovine Herpesvirus-1 in Sheep and Goats in Egypt."GlobalVeterinaria. 3 (6): 472-479, 2009

- Mohanty, S.B. and Dutta, S.K. (1981): "Veterinary virology family herpesvireade classification and nomenclature of Animal viruses." Vet. Virology, 107-116. 
- Muylkens, B.; Thiry, J.; Kirten, P.; Schynts, F.; and Thiry, E. (2007):

"Bovine herpes virus 1 infection and infectious bovine rhinotracheitis. "Vet. Res.; 38:181-209.

- Nandi, S.; Kumar, M.; Manohar, M.; and Chauhan R. (2009): "Bovine herpes virus infections in cattle."Animal Health Research Reviews.10:85-98.

- Nawal, M.A. (1997): "Prevalence of antibodies to bovine respiratory syncytial virus, infectious bovine rhinotracheitis and parainfluenza-3 in cattle and buffaloe calves." Egypt. J. Agric. Res. 75 (4): 11351145 .

- OIE (2010): Manual of diagnostic tests and vaccinesfor terrestrial animals.

- Payment, P. and Trudel, M. (1993): "Methods and techniques in virology." DNLM/DLC. Library of Congers, USA, 32-33.

- Perrin, B.; Bitsch, V.; Cordiolip; Edwards, S.; Eloit, M.; Guerin, B.; Lenihan, P., Perrin, M.; Ronsholt, L.; Van Oirschot, J.T.; Vanopdenbosch, E.; Welemans, G.; Wizigmann, G.; and Thibier, M.(1993): " A European comparative study of serological methods comparative study of serological methods for the diagnosis of infectious bovine rhinotracheitis." Rev. Sci. Rech.Of Int. Epiz., 12: 969-984.

- Salem, S.A.; Amal, S.G. and Abo- El- Hassan, D.G. (2000): "Rapid detection of BVD and IBR viruses as causes ofGenital infection in sheep and goat." 
- Santurde, G.; Silva, N.D.; Villares, R., Tabares, E.; Solana, A.; Bautista, J.M. and Castro, J.M. (1996): " Rapid and high sensitivity test for direct detection of BHV-1 genome in clinical samples."Vet. Microb. 49 (1/2): 81-92.

- Schynts, F.; Baranowski, E.; Lemaire, M.; and Thiry E. (1999): "A specific PCR to differentiate between $\mathrm{gE}$ negativevaccine and wild type bovine herpes virus type 1 strains." Vet. Microbiol., 66: 187-195.

- Smits, C.B.; Van maanen, C.; Glas, R.D.; De gee, A.L.; Dijkstrab,T.; Van oirschot J.T.; and Rijisewijk, F.A. (2000):"Comparison of three polymerase chain reaction methods for routine detection of bovine herpes virus 1 DNA in fresh bull semen." J. Virol. Methods, 85: 65-73.

- Stevens, J.G. and Groman, N.B. (1963): "Properties of infectious borinerhiotrachietis virus in quantitated virus cell culture system." Am. J. Vet. Res.(24): 1158-1163.

- Straub, O. C.; and Mackle, N. (1965):"EinAusbruch des Blachenausschlage in einor." Besamungsstationtirerarztl.Unsch, 20: 113-116.

- Straub, O.C. (1990):"Infectious Bovine Rhinotracheitis Virus. In: Virus Infections of Ruminants". (Ed. by Z.Dinter\& B.Morein), pp. 71150. Amsterdam, Elsevier Science Publishers B.V. 
- Van Engelenburg, F.A.; Kaashoek, M.J.;VanOirschot, J.T. and Rijsewijk, F.A. (1995): "A glycoprotein E deletion mutant of bovine herpesvirus 1 infects the same limited number of tissues in calves as wild-type virus, but for a shorter period." Journal of General Virology, 76 (Pt 9), 2387-2392.

- Wang, J.; O'Keefe, J.; Orr, D.; Loth, L.; Banks, M.; Wakeley, P.; West, D.; Card, R.; Ibata, G.; Van maanen, K.; Thoren P.; Isaksson, M.; and Kerkhofs P. (2008): "An international inter-laboratory ring trial to evaluate a real-time PCR assayfor the detection of bovine herpesvirus 1 in extended bovine semen." Vet. Microbiol. 126: 11-19.

- Winkler, M.T.C.; Doster, A. and Jones, C. (1999): "Bovine herpes virus-1 can infect CD4+ T-lymphocytes and induce programmed cell death during acute infection of cattle." J. Virol.73(10): 8657- 8668.

- Anonymous (2008): Manual of Diagnostic Tests and Vaccines for Terrestrial Animals. Chapter 2, 4,13Infectious Bovine Rhinotracheitis. pp. 752-763.

- Brunner, D.; Engels, M.; Schwyzer, M.; and Wyler R. (1988):"A comparison of three techniques for detecting bovineherpesvirus type $1(\mathrm{BHV}-1)$ in naturally and experimentally contaminated bovine semen." Zuchthygiene (Berlin) 23,1-9.

- Drew, T.W.; Hewitt-Taylor Watson, L.; and Edwards, S. (1987): "Effect ofstorage conditions and culture techniqueon the isolation of infectious bovine rhinotracheitisvirus from bovine semen." Vet. Rec., 121: 547-548. 
Isolation And Molecular Identification Of ...

- Meurens, F.; Schynts, F.; Keil, G.M.; Muylkens, B.; Vanderplasschen, A.; Gallego, P.; and Thiry, E. (2004):" Superinfection prevents recombination oftheAlphaherpesviruses bovine herpesvirus 1". J. Virol. 78: 3872-3879.

- Murphy, F. A., E. P. J. Gibbs, M. C. Horzinek, M. J. Studdert (1999): VeterinaryVirology. 3rd ed., Academic Press.London, Boston, New York, Sydney, Tokyo, Toronto.

- Straub, O.C., (1978):"Vorkommen der durch IBR-IPVVirenhervorgerufenen Krankheiten und mögliche Differentialdiagnostische Probleme in den verschiedenen Kontinenten und derenLänder." Deutsche Tierärztliche Wochenschrift, 85, 84-90.

- Taylor, G.; Rijsewijk, F.A.M.; Thomas, L.H.; Wyld, S.G.; Gaddum, R.M.; Cook, R.S.; Morrison, W.I., Hensen, E.; Van Oirschot, J.T.; and Keil, G. (1998):"Resistance to bovine respiratory syncytial virus (BRSV) induced incalves by a recombinant bovine herpesvirus-1 expressing theattachment glycoprotein of BRSV." J. Gen. Virol., 79: 1759-1767.

- Whitbeck, J.C.; Bello, L.J.; and Lawrence W.C. (1988): "Comparision of the bovine herpesvirus $1 \mathrm{gI}$ gene and the herpes simplex virus type 1 gB gene." J. Virol., 62 (9):3327-3319.

- Winkler, M.T.C.; Doster, A.; and Jones, C. (2000): "Persistence and reactivation of bovine herpes virus 1 in the tonsils of latently infected calves." J. Virol.74:5337-5346. 


\section{الملخص العربي}

في تلك الدراسة تم تجميع عدد 50عينة من المسحات الأنفية وعدد 93 مسحة من العين وعشرة عينات من الرئة لأبقار مصابة تعانى من أعراض تتفسية نتراوح أعمارها مابين 2-3 سنوات ولقد تم أيضا تجميع 145عينة سيرم من الحيوانات المجاورة والتي لم تظهر عليها الأعراض من أربعة محافظات مختلفة على مستوى جمهورية مصر العربية وهى الإسماعيلية - القليوبية- كفرالثيخ والفيوم. ولقد تم فحص العينات لوجود مرض الهربس- 1 ربمحاولة العزل من مسحات الأنف والعين وعينات الرئة بزرعها على خلايا الزرع النسيجي ومتابعتها لمشاهدة التغيرات المرضية التي تطراء على الخلايا. وتجميع العينات التي أحدثت تغيرات مرضية بالخلايا والتي تتفق مع التي يحدثها فيروس مرض الهربس-1 في الخلايا ولقد تم التأكيد على العزل باستخدام اختبار الفلورسنت المشع المباشر واختبار أنزيم البلمرة المنسلسل ولقد تبين من النتائج أن العزل على الخلايا أكثر حساسية من اختبار الفلورسنت المشع المباشر بالرغم من انه أسرع فى التثخيص حيث انه لا يستغرق أكثر من يوم واحد. ومن أكثر الاختبارات حساسية هو أنزيم البلمرة المنسلسل والأقل استهلاكا للوقت ومن أكثر الاختبارات المناسبة فى تتخيص مرض فيروس الهربس-1. كما انه من الأهمية قياس مستوى الأجسام المناعية في عينات المصل حيث انه من أهم صفات الفيروس انه يظل كامنا في الحيوان إلى أن بتعرض لأي نوع من الضغوط التي تؤدي إلى ظهور المرض. ولقد أوضحت النتائج أن الأجسام المناعية المضادة للفيروس موجودة في عينات السيرم التي تم فحصها في الأربع محافظات بنسب مختلفة وبالترتيب التالي التتازلي :كفر الثيخ - الإسماعيلية- القليوبية ثم الفيوم.ومن كل ما تقدم من عزل وتصنيف لفيروس الهربس-1 ومع وجود الأجسام المناعية المضادة له تأكد انه من الفيروسات النشطة الموجودة حاليا بين الأبقار فى محافظات مصر المختلفة. 